Meteorological Section of the Kratiaino Committee of the Royal Society- "that the highest air-current over the equatorial doldrums is from the eastward, lying between the south-west current which flow's on one side over the north-eat trade, and the north-west current which flows on the other side over the south-east trade."

2I Chapel Street, London, May 27.

The Structure and Distribution of Coral Reefs.

I HAVE to thank Prof. Bonney for pointing out my error in assigning the "9o-fathom reef" to Socotra instead of to Rodriguez. It arose from my having been accustomed to associate Prof. Balfour's researches with the former island.

With regard to the depths in which coral reefs can form, there has been without a doubt some little concurrence of testimony as far as the evidence goes. But I contend that all the observers were misled by supposing that the sand and reef débris, that nearly always prevent and repress the growth of corals in depths of 20 to 30 fathoms, necessarily represented the lower limit of reef-formation. We know little of the depths beyond this belt of sand and reef débris, inasmuch as the observers in question rarely extended their search beyond. The difficulties in examining these depths are much greater, and systematic soundings are greatly needecl, being in fact only practicable in the case of a surveying-vessel.

Since writing my letter I have received, through the courtesy of Captain Wharton, a copy of a report of the examination, in I888, by Commander Moore and Dr. Bassett-Smith, of H.M.S. Rambier, of the slopes and zoological condition of the Tizard and Macclesfield Banks. This report is, I believe, to be further extended by Dr. Bassett-Smith, so I will only quote here the suggestive remark of Commander Moore, respecting the Macclesfield Banl: : "Coral was found living as far down the slope as 44 fathoms ; it may extend further, but darkness put an end to the work." I should also add that a living specimen of an astræan coral was brought up from a depth of 45 fathoms in the lagoon of Tizard Reef.

Through the agency of the officers of Her Majesty's surveying ships, Captain Wharton will have soon at his disposal a large amount of new material throwing considerable light on the origin of coral reefs.

H. B. Guppy.

\section{Atmospheric Electricity.}

In NATURE of May I6 (p. 55), Mr. Bowlker describes some "curious" and, as he believes, "rare electrical phenomena" which occurred to him and a friend on the Welsh mountains. Such phenomena are rare only because competent observers are so. The effects described are by no means un common, and they may be classed under the brush discharge and the glow, the one being an interrupted, and the other a continuous, discharge to the air.

H. de Saussure gives the results of his ohservations in America, Switzerland, and other places. He remarks that the lighting-up of the rocks at night is analogous to the curious fact of electricity moving over the prairies. It is compared to a kind of miniature lightning discharge, resulting from the electrified cloud brushing over the earth, and discharging itself in thousands of sparks coursing over the meadows. In Mexico he noticed the crepitation of the stones due to electrical discharges, and in Switzerland he describes certain pricking and burning sensations, and sounds like that of simmering water, emitted from sticks laid against the rocks, and from the tops of the alpenstocks. This humming of the mountains is by no mears rare, and it seems to indicate a flow of electricity from the ground into the air.

When Prof. James Forbes was at work on the glaciers of Switzerland, he noticed on one occasion, near Mont Cervin, a curious sound proceeding from his alpenstock. The guide referred it to a worm eating the wood; he reversed the stick, and the worm was already at the other end. He raised his hand above his head, and the fingers yielded a fizzing sound, while the angular stones all round were hissing like points near an electrical machine. There was hail at the time, and a thunderstorm soon set in.

M. 'Trécul relates in the Comptes renclus the following curious case :- While writing at an open window in August 1876 , between 7 and $8 \mathrm{a} . \mathrm{m}$., he noliced a number of small luminous columns descend obliquely on his paper, each about 2 metres long, and half a decimetre broad at the widest part, obtuse at the farther end, but gradually thinning towards the table. They had mostly a reddish-jellow tint, lout near the paper the tints were more intense and varied. In disappearing they left the paper with a slight noise, like that produced by pouring a little water on a hot plate. Loud thunder was heard at the time of the observation.

In June I880, at Clarens, near the Lake of Geneva, a cherry. tree was struck by lightning, and a little girl who was about thirty paces from the tree appeared to be wrapped in a sheet of fire, while six persons, in three groups, none of them within 250 paces of the cherry-tree, were enveloped in a luminous cloud. They said they felt as if they were being struck in the face with hailstones or fine gravel, and when they touched each other, sparks passed from their fingers' ends. At the same time a luminous column was seen to descend in the direction of Chatelard, and it is stated that the electricity could be distinctly heard as it ran from point to point of the railing of the cemetery.

Mr. Jabez Brown, while ascending one of the sharp hills near Bo castle, in November, at 9 p.m., was suddenly surrounded by a bright and powerful light, which passed him a little quicker than the ordinary pace of a man's walking, leaving it as dark as before. The light was seen by the sailors in the harbour, coming in from the sea, and passing up the valley in a low cloud. A similar one occurred in Scotland last year.

Highgate, $N$.

\section{Tomlinson.}

THE electrical phenomenon described by $\mathrm{Mr}$. Bowlker in NATURE of May I6 was doubtless an instance of St. Elao's Fire ; and if it had been dark at the time it was noticed, the post, walking-stick, and other objects affected by it would have been seen to be capped with a glow resembling somewhat the brush. discharge of an electrical machine. It has been observed about fifteen times on the summit of Ben Nevis during the last five years, and these cases are described, and the accompanying weather discussed, in a paper by Mr. Rankin, of the Ben Nevis Observatory, published in the last number of the Journal of the Scottish Meteorological Society. When it occurs, all elevated points, whether metallic or not, glow; the light in the more intense cases being several inches in length. It is almo't always accompanied by a heavy fall of conical-shaped snow-flales about a quarter of an inch long, resembling hailstones in shape, but not hard or icy. At all times when it has been seen the barometric pressure has been high over the south or south-west of Europe, and low to the north of Scotland, thus giving steep gradients for westerly winds ; and in most cases the temperature on Ben Nevis has been falling, while the barometer after falling considerably has begun to rise again, and the wind to veer from south-west lowards north-west.

Ben Nevis Observatory, May 24.

\section{Sailing Flight of the Albatross,}

My attention has been drawn to some correspondence in NATURE, May 2 and 9, on the "Sailing Flight of the Albatross," in which reference is made to my father's letter to Sir William Thomson on the suject. At Sir William Thomson's suggestion, I am now about to condense the rest of my falher's correspondence on the subject into a form convenient for publication. In the meantime I will only say that while Mr. Baines's very interesting letter, and his explanation of the phenomenon of "soaring," appear to me perfectly sound in principle (and indeed we have Lord Rayleigh's authority for this view), my father's statements seem to prove that his own solution is also the true explanation of the sjaring under the (different) circumstances in which he observed it. It appears to me only reasonable to suppose that the birds instinctively learn to avail themselves of all the different natural conditions which under different circumstances may serve them to maintain their flight with the smallest exertion.

R. E. FROUDE.

Gosport, May '5

\section{The Science and Art Examination in Physics.}

'THE paper set on May I7, in Sound, Light, and Heat, presents several features that must have created dissatisfaction alike among students and teachers.

First, the official Syllabus explicitly states that the paper "will be so arranged that a candidate can secure a first class in 